\title{
Zaczyny cementowe od uszczelniania otworów wiertniczych na Niżu Polskim w trudnych warunkach geologiczno-technicznych
}

\section{Cement slurries for sealing boreholes in the Polish Lowlands in difficult geological and technical conditions}

\author{
Marcin Rzepka, Miłosz Kędzierski \\ Instytut Nafty i Gazu - Państwowy Instytut Badawczy
}

\begin{abstract}
STRESZCZENIE: Artykuł omawia zagadnienia związane z uszczelnianiem kolumn rur okładzinowych na obszarze Niżu Polskiego. W części wstępnej publikacji omówiono uwarunkowania geologiczno-techniczne panujące podczas wykonywania prac wiertniczych w głębokich otworach Niżu Polskiego oraz trudności jakie mogą wystąpić podczas realizowania wierceń. W części badawczej zaprezentowano wyniki testów receptur zaczynów cementowych prowadzonych w warunkach HPHT. Badania laboratoryjne wykonywano w Zakładzie Technologii Wiercenia w Instytucie Nafty i Gazu - Państwowym Instytucie Badawczym. Ramowe składy receptur zaczynów cementowych opracowane zostały w INiG - PIB przy współpracy z Serwisem Cementacyjnym działającym przy firmie Exalo należącej do grupy PGNiG. Testy zaczynów cementowych wykonywane były zgodnie z normami: Przemyst naftowy $i$ gazowniczy - Cementy i materiały do cementowania otworów - Część 1: Specyfikacja (PN-EN ISO 10426-1:2009) oraz Przemyst naftowy i gazowniczy - Cementy i materiały do cementowania otworów wiertniczych - Część 2: Badania cementów wiertniczych (PN-EN ISO 10426-2:2003). Zaczyny cementowe sporządzano na bazie 10\% lub 20\% solanki NaCl. W testowanych recepturach jako spoiwo wiążące zastosowano cement wiertniczy G HSR o wysokiej odporności na siarczany. Do uszczelniania kolumn rur o średnicy 95/8” zaproponowano dwa rodzaje zaczynów: „lekkie” oraz o „normalnej” gęstości, które badano w temperaturze $80^{\circ} \mathrm{C}$. Dla kolumny rur o średnicy 7" zamieszczono propozycję ciężkich zaczynów cementowych (o regulowanej gęstości) testowanych w $95^{\circ} \mathrm{C} \mathrm{i} 120^{\circ} \mathrm{C}$. Z kolei dla kolumn rur o średnicy 5 ” opracowano receptury o „normalnej” gęstości dla temperatur $130^{\circ} \mathrm{C} \mathrm{i} 160^{\circ} \mathrm{C}$. Wprowadzenie do zaczynu dodatków obniżających gęstość (w przypadku zaczynu górnego dla rur o średnicy 95/8”) pozwoliło na uzyskanie receptur o regulowanej gęstości od około 1500-1650 kg/m $\mathrm{m}^{3}$. Z kolei dodatek obciążający (dodawany do receptur proponowanych do uszczelniania rur 7”) pozwolił na opracowanie zaczynów o gęstości w granicach od około 2060 do około $2350 \mathrm{~kg} / \mathrm{m}^{3}$. Zastosowanie odpowiednio dobranych opóźniaczy wiązania nowej generacji, umożliwiło sporządzanie receptur dla bardzo wysokich temperatur (do $\left.160^{\circ} \mathrm{C}\right)$. Opracowane receptury zaczynów mogą znaleźć zastosowanie w procesie cementowania kolumn rur okładzinowych podczas prac prowadzonych na Niżu Polskim w trudnych warunkach geologiczno-technicznych.
\end{abstract}

Słowa kluczowe: zaczyn cement, kamień cementowy, wysoka temperatura, wysokie cieśninie, cementowanie.

ABSTRACT: The article discusses issues related to casing pipe columns sealing in the Polish Lowlands. The introductory part of the publication presents geological and technical conditions prevailing during drilling the deep boreholes in the Polish Lowlands and difficulties that may occur during drilling. The authors present the results of cement slurries recipies tests conducted under HPHT conditions. Laboratory tests were carried out at the Drilling Technology Department in Oil and Gas Institute - National Research Institute. Slurry recipes had been developed in the Oil and Gas Institute - NRI in collaboration with the Cementing Service operating at the Exalo company belonging to the PGNiG group. Cement slurry tests were carried out in accordance with the following standards: Petroleum and natural gas industries - Cements and materials for well cementing - Part 1: Specification (PN-EN ISO 10426-1:2009) and Petroleum and natural gas industries - Cements and materials for well cementing - Part 2: Testing of well cements (PN-EN ISO 10426-2:2003). Cement slurries were prepared with $10 \%$ or $20 \% \mathrm{NaCl}$ brine as a base. The G HRS cement with high sulfate resistance was used as a binder. Two types of slurry were proposed for sealing $95 / 8$ " casing: "lightweight" and "normal" density, which were tested at $80^{\circ} \mathrm{C}$. High-density cement slurries (with adjustable density) tested at $95^{\circ} \mathrm{C}$ and $120^{\circ} \mathrm{C}$ were proposed for $7^{\prime}$ " casing column. In turn, for 5 " casing column recipes with "normal" density were developed for temperatures of $130^{\circ} \mathrm{C}$ and $160^{\circ} \mathrm{C}$. The application of density-reducing additives to the slurry (in the case of lead cement slurry of $95 / 8$ " casing) allowed us to obtain formulations with adjustable density from 1500 to $1650 \mathrm{~kg} / \mathrm{m}^{3}$. In turn, the weighting material added to the slurries for sealing 7" casings allowed us to

Autor do korespondencji: M. Rzepka, e-mail: marcin.rzepka@inig.pl

Artykuł nadesłano do Redakcji: 6.11.2019 r. Zatwierdzono do druku: 27.01.2020 r. 
develop slurries with a density ranging from 2060 to $2350 \mathrm{~kg} / \mathrm{m}^{3}$. The use of appropriately selected new generation setting retarders made it possible to prepare formulations for very high temperatures (up to $160^{\circ} \mathrm{C}$ ). The developed cement slurry formulations can be used in the process of cementing casing columns in boreholes in the Polish Lowlands in difficult geological and technical conditions.

Key words: cement slurry, set cement, high temperature, high pressure, cementing.

\section{Wprowadzenie}

Firmy naftowe w naszym kraju w ostatnich latach coraz częściej wykonują wiercenia otworów, których końcowe głębokości sięgają ponad czterech tysięcy metrów. Dzieje się tak szczególnie na obszarze Niżu Polskiego, gdzie złoża węglowodorów zalegają przeważnie poniżej $3-3,5 \mathrm{~km}$ pod powierzchnią ziemi. Temperatury dynamiczne panujące na dnie tych otworów wynoszą około $120-130^{\circ} \mathrm{C}$ lub nawet przewyższają te wartości. Według informacji napływających z przemysłu w najbliższych latach planowane są kolejne wiercenia głębokich otworów w tym rejonie (Rzepka et al., 2012; Rzepka i Kremieniewski, 2017).

Jak wiadomo, na dużych głębokościach w otworze wiertniczym panują specyficzne warunki. W zależności od głębokości oraz budowy geologicznej górotworu zmienia się stopień geotermiczny a tym samym temperatura statyczna i dynamiczna (Souza et al., 2012; Salim i Amani, 2013). W różnych utworach geologicznych zmieniają się także gradienty ciśnienia złożowego i szczelinowania. Ciśnienie hydrostatyczne w otworze wiertniczym zależy od wysokości i gęstości cieczy wiertniczej (np. na głębokości około 3000 metrów w przypadku ciężkiego zaczynu cementowego ciśnienie to może wynosić około $70 \mathrm{MPa}$ ). Solanki złożowe w dużym stopniu oddziaływają na stwardniały zaczyn cementowy (szczególnie agresywne w stosunku do płaszcza cementowego są jony $\mathrm{Mg}^{+2}, \mathrm{SO}_{4}^{-2}$, zawarte w wodach złożowych oraz gaz toksyczny - siarkowodór). Dlatego też zaczyny przeznaczone do zatłaczania na dużych głębokościach powinny zawierać w swoim składzie m.in. dodatki i domieszki podnoszące wytrzymałość kamienia cementowego w wysokiej temperaturze oraz poprawiające odporność korozyjną płaszcza cementowego (Rzepka i Stryczek, 2008).

Przy dużych głębokościach otworu poważnym problemem jest zatem zapewnienie długiego czasu przetłaczalności zaczynu cementowego, który powinien charakteryzować się niską lepkością, niewielkim odstojem wody oraz jak najniższą filtracją. Głównym zadaniem stojącym przed projektantem receptur cementowych jest zatem odpowiednie dopasowanie środków opóźniających, upłynniających oraz spoiwa wiążącego, które będą odporne na działanie warunków HPHT oraz dobór innych dodatków i domieszek zapewniających prawidłowe parametry technologiczne zaczynu i kamienia cementowego (Bensted, 1991).

\section{Ogólna charakterystyka warunków panujących podczas prac wiertniczych w głębokich otworach Niżu Polskiego oraz trudności jakie mogą wystąpić podczas wiercenia}

Rejon Niżu Polskiego zaliczany jest do obszarów o dużych trudnościach wiertniczych. Wynika to głównie ze skomplikowanej budowy geologicznej obszaru, na którym występują między innymi aktywne czerwone iły solne, wysokie gradienty ciśnienia złożowego $\mathrm{w}$ dolomicie głównym oraz inne możliwe problemy jakie mogą wystąpić podczas prowadzenia prac związanych z głębieniem otworu (Nalepa, 2001). W tabeli 1 przedstawiono uproszczony profil stratygraficzny przykładowego otworu G-1 o głębokości 3750 metrów

Tabela 1. Przykładowy uproszczony profil stratygraficzny otworu G-1 o głębokości 3750 m (zaznaczono najważniejsze poziomy stratygraficzne - głębokości zalegania podano $\mathrm{z}$ dokładnością do 10 metrów)

Table 1. An example of a simplified stratigraphic profile of the G-1 borehole with a depth of $3750 \mathrm{~m}$ (the most important stratigraphic levels are marked - the deposition depths are given with an accuracy of 10 meters)

\begin{tabular}{|c|c|c|}
\hline \multicolumn{2}{|r|}{ Stratygrafia } & $\begin{array}{c}\text { Strop warstwy } \\
{[\mathrm{m}]}\end{array}$ \\
\hline \multicolumn{2}{|c|}{ KENOZOIK } & 0 \\
\hline \multirow{6}{*}{ 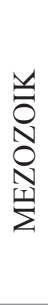 } & KREDA & 220 \\
\hline & JURA & 880 \\
\hline & TRIAS & 1360 \\
\hline & Retyk & 1360 \\
\hline & Kajper & 1550 \\
\hline & Wapień muszlowy & 1880 \\
\hline \multirow{12}{*}{ 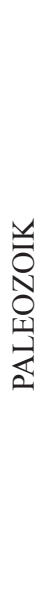 } & PERM & 2670 \\
\hline & cechsztyn w tym: & 2670 \\
\hline & sól najmłodsza & 2680 \\
\hline & czerwony ił solny & 2740 \\
\hline & sól młodsza & 2750 \\
\hline & anhydryt główny & 2910 \\
\hline & anhydryt podstawowy & 3400 \\
\hline & dolomit główny & 3410 \\
\hline & sól najstarsza & 3480 \\
\hline & anhydryt dolny & 3540 \\
\hline & czerwony spągowiec & 3590 \\
\hline & Głębokość końcowa & 3750 \\
\hline
\end{tabular}


zlokalizowanego na złożu węglowodorów w okolicy Międzychodu. Schemat zarurowania tego otworu zamieszczono w tabeli 2, natomiast zastawienie gradientów ciśnień (warunkujących między innymi gęstości używanych płynów wiertniczych) w tabeli 3. Kolumna rur 185/8" zapuszczana jest do głębokości 40 m. Następnie, w warstwach kredy, zapuszczana i cementowana jest kolumna rur $13 \%$ ". Rury okładzinowe o średnicy 95/8" - posadowiane i uszczelniane są w warstwach soli najmłodszej, rury 7" - w anhydrycie dolnym, a rury 5" - w warstwach czerwonego spągowca. Temperatura dynamiczna panująca na dnie otworu wynosi około $135^{\circ} \mathrm{C}$. W tabeli 4 zestawiono przewidywane występowanie węglowodorów (możliwe przypływy gazu) i wód złożowych (solanek) oraz trudności jakie mogą wystąpić w czasie wiercenia, tj.: sypanie, zaniki płuczki, kawernowanie ścian otworu, dopływy $\mathrm{H}_{2} \mathrm{~S}$, zagrożenie erupcyjne i in. (Herman i Migdał, 1998; Stryczek i Gonet, 2001). otworu
Tabela 2. Schematy zarurowania i cementowania otworu

Table 2. Schemes of borehole casing and cementing

\begin{tabular}{|c|c|c|}
\hline Zarurowanie & $\begin{array}{c}\text { Interwal } \\
{[\mathbf{m}]}\end{array}$ & Uwagi odnośnie do cementowania rur \\
\hline \hline $185 / 8 "$ & $0-40$ & rury cementowane do wierzchu (c.d.w.) \\
\hline $13 \%$ 3 $"$ & $0-270$ & rury cementowane do wierzchu (c.d.w.) \\
\hline $95 \%$ ' & $0-2710$ & rury cementowane do wierzchu (c.d.w.) \\
\hline Liner 7" & $2560-3585$ & liner cementowany na całej długości \\
\hline Liner 5" & $3350-3750$ & liner cementowany na całej długości \\
\hline
\end{tabular}

Tabela 3. Przybliżone gradienty ciśnień złożowych i szczelinowania występujące w profilu

Table 3. Approximate formation pressure and fracture gradient occurring in the well profile

\begin{tabular}{|c|c|c|}
\hline \multirow{2}{*}{ Poziom stratygraficzny } & $\begin{array}{c}\text { Gradient } \\
\text { ciśnienia złożowego }\end{array}$ & $\begin{array}{c}\text { Gradient } \\
\text { ciśnienia szczelinowania }\end{array}$ \\
\cline { 2 - 3 } & \multicolumn{2}{|c|}{$[\mathbf{M P a} / \mathbf{m}]$} \\
\hline \hline Kenozoik & 0,0098 & 0,0127 \\
\hline Kreda i jura & 0,0102 & 0,0130 \\
\hline Trias & 0,0106 & 0,0147 \\
\hline Wapień muszlowy & 0,0108 & 0,0150 \\
\hline Cechsztyn - dolomit główny & $0,014-0,018$ & $0,020-0,023$ \\
\hline Czerwony spągowiec & 0,0110 & 0,0150 \\
\hline
\end{tabular}

Tabela 4. Przewidywane występowanie węglowodorów i wód złożowych oraz trudności jakie mogą wystąpić w czasie wiercenia Table 4. The expected presence of hydrocarbons and formation water and problems that can occur during a drilling operation

\begin{tabular}{|c|l|}
\hline Poziom stratygraficzny & \multicolumn{1}{c|}{$\begin{array}{c}\text { Przewidywane występowanie horyzontów wodonośnych i zlóż weglowodorów } \\
\text { oraz przewidywane trudności podczas wiercenia }\end{array}$} \\
\hline \hline Kenozoik & Możliwe występowanie wód słodkich. Możliwe sypanie i kawernowanie ścian otworu \\
\hline Kreda i jura & $\begin{array}{l}\text { Spodziewane horyzonty wód zmineralizowanych lub solanek złożowych. Możliwe zaniki płuczki, sypanie } \\
\text { i kawernowanie ścian otworu }\end{array}$ \\
\hline Trias & $\begin{array}{l}\text { Możliwe występowanie solanek złożowych. Możliwe sypanie ścian otworu, przypływy solanki lub zaniki płuczki } \\
\text { (głównie w utworach retyku i kajpru) }\end{array}$ \\
\hline Cechsztyn & $\begin{array}{l}\text { W poziomie dolomitu głównego możliwy przypływ węglowodorów i solanki ze znaczną zawartością } \mathrm{H}_{2} \mathrm{~S} \\
\text { W dolomicie głównym klasa zagrożenia erupcyjnego - A, kategoria zagrożenia } \mathrm{H}_{2} \mathrm{~S}-\text { III } \\
\text { W osadach cechsztyńskich możliwość zaciskania ścian otworu przez plastyczne czerwone iły solne }\end{array}$ \\
\hline Czerwony spągowiec & $\begin{array}{l}\text { Możliwy przypływ gazu ziemnego } \\
\text { W utworach czerwonego spągowca klasa zagrożenia erupcyjnego - B }\end{array}$ \\
\hline
\end{tabular}

\section{Środki modyfikujące stosowane w zaczynach cementowych używanych podczas uszczelniania głębokich otworów wiertniczych na Niżu Polskim}

Uszczelnianie głębokich otworów wiertniczych zwłaszcza w końcowych interwałach wiąże się z koniecznością opracowania odpowiednich receptur zaczynów cementowych, odpornych na wysoką temperaturę i ciśnienie (Nelson, 1990). Dodatkowo w rejonie Niżu Polskiego niezbędne jest utrzymanie zasolenia zaczynu w ilości od $10 \%$ do $20 \% \mathrm{NaCl}$ w zależności od potrzeb. Poza tym, podczas projektowania receptury, opracowany zaczyn i powstały z niego kamień powinien być najdłużej trwały w warunkach działania zmineralizowanych wód złożowych o dużej zawartości jonów agresywnych czy też siarkowodoru (tj. jak najwolniej ulegać korozji). Dlatego niezbędne jest zastosowanie do zaczynów uszczelniających wielu dodatków i domieszek modyfikujących recepturę cementową (Gonet et al., 2004; Anjos et al., 2013). Należą do nich między innymi:

- odpieniacze, które redukują ilość powietrza zawartego w zaczynie cementowym;

- upłynniacze (plastyfikatory), które obniżają lepkość zaczynu i regulują jego parametry reologiczno-strukturalne;

- środki antyfiltracyjne i redukujące odstój wody, które 
zabezpieczają przed utratą wody z zaczynu oraz sedymentacją fazy stałej;

- opóźniacze czasu gęstnienia i wiązania, które pozwolą bezpiecznie przepompować zaczyn cementowy do uszczelnianej przestrzeni pierścieniowej;

- dodatki zapobiegające migracji gazu (np. lateksy) poprawiające jednocześnie szczelność matrycy cementowej i jej odporność na korozję;

- krzemionka (mikrosilica), wprowadzana do receptury w celu podniesienia odporności termicznej kamienia cementowego. Szczególne znaczenie odgrywają tu tzw. opóźniacze czasu wiązania zaczynu, które w wysokich temperaturach pozwalają wydłużyć proces hydratacji i utrzymać tłoczony zaczyn w stanie płynnym przez cały okres czasu, w którym następuje proces cementowania.

W literaturze (Dębińska, 2012; Boul at al., 2016) podaje się kilka teorii wyjaśniających mechanizm działania opóźniaczy. Są to teorie:

- $\quad$ adsorpcji - w której opóźnienie wiązania zaczynu związane jest $\mathrm{z}$ adsorpcją opóźniacza na powierzchni produktów hydratacji, a co się z tym wiąże utrudnionym kontakcie ziaren cementu z wodą;

- wytrącania - opóźniacz reaguje z cementem w fazie wodnej tworząc przez pewien czas nierozpuszczalną i nieprzepuszczalną warstwę wokół ziaren cementu;

- krystalizacji - opóźniacz adsorbuje się na kryształach produktów hydratacji i opóźnia bądź niszczy ich dalszy wzrost, W praktyce wszystkie wymienione czynniki mogą się ze sobą łączyć, dając ogólny efekt w postaci spowolnionego procesu hydratacji zaczynu w warunkach HPHT.

Do stosowanych obecnie na świecie środków opóźniających można zaliczyć między innymi: lignosulfoniany, kwasy hydrokarboksylowe, pochodne celulozy, fosforany czy też używane ostatnio nowoczesne komponenty nieorganiczne o zastrzeżonym przez producentów składzie.
Najczęściej stosowanymi w zaczynach cementowych środkami opóźniającymi są sole wapnia i sodu kwasów lingosulfonowych. Związki lingosuflonowe powstają jako produkt uboczny przy produkcji celulozy. Sa one bardzo efektywne w stosunku do większości grup cementów, a ich koncentracja waha się od około $0,05 \%$ do $1,5 \%$ bwoc (tj. w stosunku do masy suchego cementu).

\section{Badania laboratoryjne zaczynów i kamieni cementowych proponowanych do uszczelniania rur okładzinowych w otworach na Niżu Polskim}

Badania laboratoryjne dla zaczynów cementowych przeznaczonych do głębokich otworów wiertniczych wykonywane były zgodnie z normami: Przemyst naftowy i gazowniczy - Cementy i materiaty do cementowania otworów - Część 1: Specyfikacja (PN-EN ISO 10426-1:2009) oraz Przemyst naftowy $i$ gazowniczy - Cementy i materiaty do cementowania otworów wiertniczych-Część 2: Badania cementów wiertniczych (PN-EN ISO 10426-2:2003). W badanych zaczynach cementowych jako spoiwo wiążące zastosowano cement wiertniczy G HSR (o wysokiej odporności na siarczany). Skład cementu podano w tabeli 5. Użyty w badaniach cement spełniał wszystkie wymagania obowiązującej normy i był wykorzystywany tak w badaniach prowadzonych w INiG - PIB, jak i w serwisach wykonujących zabiegi cementowania rur okładzinowych w Polsce.

Zastosowanie cementu G HSR na Niżu Polskim jest podyktowane występowaniem znacznych ilości siarkowodoru w gazie ziemnym. Przykładowe stężenia $\mathrm{H}_{2} \mathrm{~S}$ w wybranych odwiertach przedstawiono w tabeli 6. Jak wynika $\mathrm{z}$ tych danych stężenie siarkowodoru w gazie ziemnym wynosi od kilku do kilkunastu procent objętości gazu ziemnego (z reguły jednak jest to kilka procent).

Tabela 5. Wymagany skład chemiczny cementu wiertniczego klasy G HSR odpornego na działanie siarczanów (według normy PN-EN ISO 10426-1:2009)

Table 5. Required chemical composition of well cement class G (HSR) high sulfate-resistant (according to PN-EN ISO 10426-1:2009)

\begin{tabular}{|l|c|}
\hline \multicolumn{2}{|c|}{ CEMENT WIERTNICZY klasy G - gatunek wysokoodporny na dzialanie siarczanów (HSR) } \\
\hline \multicolumn{1}{|c|}{ Skladnik cementu G HSR } & (PN-EN ISO 10426-1:2009) \\
\hline \hline Tlenek magnezu $(\mathrm{MgO})$, co najwyżej, procent & 6,0 \\
\hline Trójtlenek siarki $\left(\mathrm{SO}_{3}\right)$, co najwyżej, procent & 3,0 \\
\hline Strata prażenia, co najwyżej, procent & 3,0 \\
\hline Pozostałość nierozpuszczalna, co najwyżej, procent & 0,75 \\
\hline Krzemian trójwapniowy $\left(\mathrm{C}_{3} \mathrm{~S}\right)$ co najmniej - co najwyżej, (od - do), procent & $48-65$ \\
\hline Glinian trójwapniowy $\left(\mathrm{C}_{3} \mathrm{~A}\right)$, co najwyżej, procent & 3 \\
\hline Glinożelazian czterowapniowy $\left(\mathrm{C}_{4} \mathrm{AF}\right)$ plus dwa razy glinian trójwapniowy $\left(\mathrm{C}_{3} \mathrm{~A}\right)$, co najwyżej, procent & 24 \\
\hline Ogólna zawartość alkaliów wyrażona jako równoważnik tlenku sodu $\left(\mathrm{Na}_{2} \mathrm{O}\right)$, co najwyżej, procent & 0,75 \\
\hline
\end{tabular}


Tabela 6. Zestawienie zawartości $\mathrm{H}_{2} \mathrm{~S}$ w składzie gazu ziemnego na w wybranych otworach na Niżu Polskim

Table 6. List of $\mathrm{H}_{2} \mathrm{~S}$ content in the natural gas composition in selected wells in the Polish Lowlands

\begin{tabular}{|c|c|}
\hline \multirow{2}{*}{$\begin{array}{c}\text { Symbol odwiertu } \\
\text { na Niżu Polskim }\end{array}$} & $\begin{array}{c}\text { Zawartość procentowa } \mathbf{H}_{2} \mathbf{S} \\
\text { w skladzie gazu ziemnego }\end{array}$ \\
\cline { 2 - 2 } & $\mathbf{H}_{2} \mathbf{S}[\%]$ \\
\hline \hline L-4 & 7,39 \\
\hline G-2 & 4,58 \\
\hline S-G 1 & 8,00 \\
\hline
\end{tabular}

\begin{tabular}{|c|c|}
\hline \multirow{2}{*}{$\begin{array}{c}\text { Symbol odwiertu } \\
\text { na Niżu Polskim }\end{array}$} & $\begin{array}{c}\text { Zawartość procentowa } \mathbf{H}_{2} \mathbf{S} \\
\text { w składzie gazu ziemnego }\end{array}$ \\
\cline { 2 - 2 } & $\mathbf{H}_{2} \mathbf{S}[\%]$ \\
\hline \hline S-G 2 K & 13,32 \\
\hline B-6 & 14,82 \\
\hline B-9 & 11,09 \\
\hline
\end{tabular}

Destrukcyjne oddziaływanie siarkowodoru na stwardniały zaczyn cementowy polega na wywołaniu reakcji korozji kwasowej, opisanej w następujący sposób:

$$
\begin{gathered}
\mathrm{Ca}(\mathrm{OH})_{2}+\mathrm{H}_{2} \mathrm{~S} \rightarrow \mathrm{CaS}+2 \mathrm{H}_{2} \mathrm{O} \\
\mathrm{CaS}+\mathrm{H}_{2} \mathrm{~S} \rightarrow \mathrm{Ca}(\mathrm{HS})_{2}
\end{gathered}
$$

Powolny rozpad kamienia zachodzi na skutek eliminowania ze stwardniałego zaczynu cementowego wodorotlenku wapniowego (portlandytu). Po usunięciu lub zmniejszeniu koncentracji $\mathrm{Ca}(\mathrm{OH})_{2}$ dochodzi do rozkładów uwodnionych krzemianów i glinianów wapniowych (Brylicki, 2001).

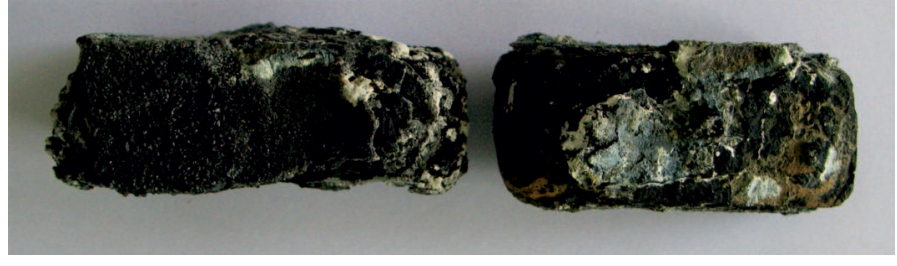

Rys. 1. Wygląd próbki stwardniałego zaczynu cementowego nieodpornego na $\mathrm{H}_{2} \mathrm{~S}$, deponowanego w wodzie złożowej nasyconej siarkowodorem (wytrzymałość na ściskanie około 1,5-2 MPa)

Fig. 1. Sample of set cement not resistant to $\mathrm{H}_{2} \mathrm{~S}$, deposited in formation water saturated with hydrogen sulfide (compressive strength 1.5-2.0 MPa) Powstały w wyniku reakcji chemicznej wodorosiarczek wapnia, znajdujący się w stwardniałym zaczynie, jest dobrze rozpuszczalny w wodzie i może być łatwo wypłukany z matrycy cementowej. Korozja wywołana działaniem $\mathrm{H}_{2} \mathrm{~S}$ jest procesem dyfuzyjnym. Decydującą rolę odgrywa w niej dyfuzja kationów wodorowych i anionów reszty kwasowej w głąb matrycy stwardniałego zaczynu cementowego. Kamień cementowy sporządzony z cemen-

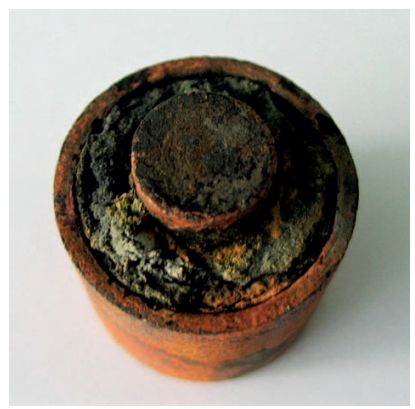

Rys. 2. Wygląd stwardniałego zaczynu cementowego, wypełniającego przestrzeń pierścieniową pomiędzy dwoma stalowymi rurami. Próbka deponowana w wodzie złożowej nasyconej siarkowodorem

Fig. 2. Set cement filling the annular space between two steel pipes. The sample was deposited in formation water saturated with hydrogen sulfide

tu nieodpornego na $\mathrm{H}_{2} \mathrm{~S}$ posiada wysoką podatność na korozję i może ulegać szybkiej destrukcji. Rysunek 1 (belka stwardniałego zaczynu w nieosłoniętej przestrzeni) i rysunek 2 (kamień cementowy wypełniający przestrzeń międzyrurową) obrazują wygląd próbek stwardniałych zaczynów cementowych testowanych w INiG - PIB na bazie cementu o małej odporności na korozję siarczanową po 36 miesiącach ekspozycji. Kamień cementowy „nieosłonięty” widoczny na rysunku 1. skorodował bardzo wyraźnie. Próbka uległa praktycznie całkowitemu rozpadowi. Kamień cementowy wypełniający przestrzeń międzyrurową (rys. 2) wolniej ulegał korozji (oznaki destrukcji widoczne są jedynie w strefie bezpośredniego kontaktu z solanką nasyconą $\mathrm{H}_{2} \mathrm{~S}$ ). Próbkę ,nieosłoniętą" eksponowaną 36 miesięcy i sporządzoną z cementu o podwyższonej odporności na siarczany, tj. cementu G HSR zamieszczono na rysunku 3. Próbka ta wykazywała minimalne oznaki destrukcji (znacznie mniejsze jak w przypadku próbki z rysunku 1), a jej wytrzymałość na ściskanie była około dziesięciokrotnie wyższa niż analogicznej próbki sporządzonej z cementu nieodpornego na siarczany.

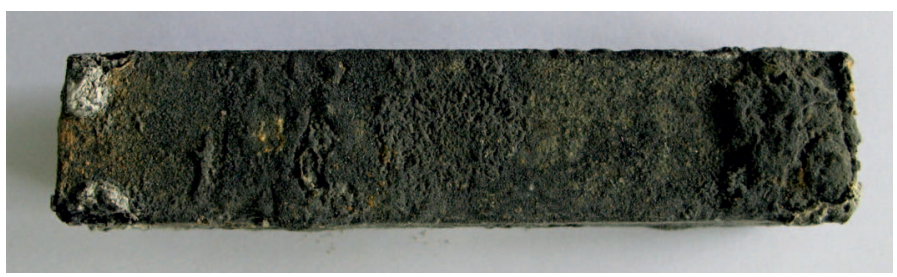

Rys. 3. Wygląd próbki stwardniałego zaczynu cementowego o podwyższonej odporności na $\mathrm{H}_{2} \mathrm{~S}$, Próbka deponowana w wodzie złożowej nasyconej siarkowodorem (wytrzymałość na ściskanie $16,3 \mathrm{MPa}$ )

Fig. 3. Sample of set cement with increased resistance to $\mathrm{H}_{2} \mathrm{~S}$. The sample was deposited in formation water saturated with hydrogen sulfide (compressive strength 16.3 MPa)

\section{Receptury zaczynów proponowane do uszczelniania poszczególnych kolumn rur okładzinowych}

Ramowe składy receptur zaczynów cementowych opracowane zostały w Instytucie Nafty i Gazu - Państwowym Instytucie Badawczym przy współpracy z Serwisami Cementacyjnymi działającym przy firmie Exalo należącej do grupy PGNiG. 
Uwaga:

Podano orientacyjne przedziały głębokości zapuszczania poszczególnych rur okładzinowych podczas wykonywania prac wiertniczych na Niżu Polskim. Jako zaczyny lekkie traktowano te receptury, których gestości byty mniejsze od $1700 \mathrm{~kg} / \mathrm{m}^{3}$. Zaczyny o ciężarze około $1800-1900 \mathrm{~kg} / \mathrm{m}^{3}$ określano mianem receptur o „,normalnej” gestości. Zaczyny o ciężarze ponad $2000 \mathrm{~kg} / \mathrm{m}^{3}$ traktowano jako ciężkie.

\section{Receptury zaczynów do uszczelniania rur oktadzinowych o średnicach 185\%" oraz 13\%”, (w glębokości od kilkudziesięciu do kilkuset metrów)}

Receptury zaczynów do uszczelniania początkowych kolumn rur okładzinowych, tj. 185/8" czy 133/." nie są skomplikowane, a ich przygotowanie nie sprawia znaczących problemów. Są to zwykle zaczyny o niedużej liczbie składników na bazie cementu portlandzkiego zarabiane wodą słodką z dodatkiem przyśpieszacza wiązania i upłynniacza oraz ewentualnie niewielkich ilości innych dodatków modyfikujących. W przypadku konieczności zastosowania dwóch partii zaczynów do górnego (lżejszego) wprowadza się bentonit i mikrosfery w zależności od potrzeb. Jeśli chodzi o ich ewentualną modyfikację możliwe jest dodatkowe wprowadzenie 10-20\% mikrocementu w celu poprawy ich wytrzymałości mechanicznej (choć w praktyce nie jest to niezbędne). Zaczyny takie o gęstości około $1500-1650 \mathrm{~kg} / \mathrm{m}^{3}$ (górny) i około $1800-1850 \mathrm{~kg} / \mathrm{m}^{3}$ (dolny) badane w Laboratorium INiG - PiB posiadały bardzo dobre parametry technologiczne, zerowe odstoje wody i odpowiednie czasy wiązania.

\section{Receptury zaczynów do uszczelniania technicznych kolumn rur okladzinowych o średnicy 95\%”- posadawianych w soli najmtodszej (w glębokości okoto 2300-2900 metrów)}

Do uszczelniania kolumn rur technicznych $95 / 8$ " stosuje się najczęściej dwie partie zaczynów cementowych: górne (lekkie) oraz dolne (o „normalnej” gęstości). W INiG - PIB wykonano badania szeregu tych zaczynów w temperaturze $80^{\circ} \mathrm{C}$ zarabianych $20 \%$ solanką $\mathrm{NaCl}$ na bazie cementu G HSR. W skład zaczynów wchodziły dodatki odpieniające, upłynniające, antyfiltracyjne oraz opóźniacze wiązania. Zaczyny zawierały także mikrocement. W tablicy 7 oraz 8 zamieszczono przykładowe receptury oraz uzyskane wyniki badań. Zaczyny oznaczane symbolami A oraz B (tzw. górne) cechowały się obniżoną gęstością (wynoszącą odpowiednio 1530 i $1620 \mathrm{~kg} / \mathrm{m}^{3}$ ), którą uzyskano stosując zwiększony współczynnik wodno-cementowy oraz dodatki bentonitu i mikrosfer. Zaczyny C oraz D (tzw. dolne) posiadały „normalną” gęstość (wynoszącą 1820 i $1850 \mathrm{~kg} / \mathrm{m}^{3}$ ). Wszystkie badane zaczyny nie posiadały odstoju wody i cechowały się odpowiednimi parametrami reologicznymi. Czasy gęstnienia zaczynów opracowano w ten sposób, aby możliwe było bezpieczne zatłoczenie ich do przestrzeni pierścieniowej (początki gęstnienia $30 \mathrm{Bc}$ wynosiły w zależności od receptury około $5-5 \frac{1}{2}$ godziny). Filtracje zaczynów nie przekraczały $200 \mathrm{~cm}^{3} / 30$ minut. Wytrzymałości na ściskanie kamieni cementowych powstałych $\mathrm{z}$ badanych receptur zamieszczono na rysunku 4. Zaczyny lekkie w okresie od 2 do 7 dni posiadały wytrzymałość na ściskanie wynoszące około 14-17 MPa. W tym samym okresie czasu wytrzymałość zaczynów o „normalnej" gęstości wynosiła około 20-24 MPa.

\section{Receptury zaczynów do uszczelniania rur okladzinowych o średnicy 7 cali (liner 7") - posadawianych w anhydrycie dolnym (w glębokości okoto 3100-3700 metrów)}

Uszczelnianie rur 7" odbywa się przy użyciu ciężkich zaczynów cementowych z uwagi na podwyższone wartości gradientów ciśnienia złożowego. W INiG - PIB opracowano szereg receptur obciążonych zaczynów o gęstości od okoto $2000-2400 \mathrm{~kg} / \mathrm{m}^{3}$. Zaczyny te badano w temperaturach od około $90^{\circ} \mathrm{C}$ do około $120^{\circ} \mathrm{C}$. Zaczyny zarabiane były $10 \%$ solanką $\mathrm{NaCl}$. Sporządzano je na bazie cementu wiertniczego G HSR. Do receptur wprowadzano między innymi lateks (około $20 \%$ ) a także dodatki odpieniające, upłynniające, obniżające filtrację oraz opóźniające wiązanie. Przykładowe składy receptur i uzyskane wyniki dla czterech zaczynów oznaczonych symbolami E, F, G i H zamieszczono w tabeli 9 i 10. W celu uzyskania wymaganej gęstości do zaczynów wprowadzano od $30 \%$ do $110 \%$ (bwoc - w stosunku do masy suchego cementu) materiału obciążającego. Poprawę wytrzymałości mechanicznej w wysokiej temperaturze uzyskiwano dzięki dodaniu do składów mączki krzemionkowej. Zaczyny uszeregowano w kolejności rosnącej gęstości od $2060 \mathrm{~kg} / \mathrm{m}^{3}$ (zaczyn najlżejszy - E) do $2350 \mathrm{~kg} / \mathrm{m}^{3}$ (zaczyn najcięższy - H). Odstoje wody $\mathrm{z}$ badanych zaczynów były zerowe. Zaczyny posiadały lepkości plastyczne o około 115 do $220 \mathrm{mPa} \cdot \mathrm{s}$ (w zależności od ilości dodawanego środka obciążającego). Czasy początku gęstnienia (30 Bc) badanych zaczynów wynosiły od okoto $3^{1 / 2}$ do $4 \frac{1}{2}$ godziny natomiast ich filtracje nie przekraczały $50 \mathrm{~cm}^{3} / 30$ minut. Na rysunku 5 zamieszczono wyniki badań wytrzymałości na ściskanie omawianych próbek (w okresie od 2 do 7 dni ich wytrzymałość na ściskanie wynosiła okoto $23-28 \mathrm{MPa}$ ).

\section{Receptury zaczynów do uszczelniania rur oktadzinowych 5 cali (liner 5") - posadawianych w warstwach czerwonego spagowca (w glębokości okoto 3400-3900 metrów)}

W niektórych przypadkach, po przewierceniu cechsztynu, w projekcie otworu przewidziane jest zapuszczanie i cementowamie kolejnej kolumny rur (linera 5") w stropie czerwonego spągowca. Gradienty ciśnienia złożowego są tam 
Tabela 7. Składy zaczynów cementowych dla kolumn rur technicznych (temperatura badania $80^{\circ} \mathrm{C}-$ rury $95 / 8$ )

Table 7. Compositions of cement slurries for $9 \frac{5}{8}{ }^{\prime \prime}$ intermediate casing tested at $80^{\circ} \mathrm{C}$

\begin{tabular}{|c|c|c|c|c|}
\hline $\begin{array}{c}\text { Symbol zaczynu temperatura i ciśnienie/ } \\
\text { Skladniki w [\%] bwoc }{ }^{*}\end{array}$ & $\begin{array}{c}\text { Zaczyn A } \\
\left(80^{\circ} \mathrm{C} / 40 \mathrm{MPa}\right)\end{array}$ & $\begin{array}{c}\text { Zaczyn B } \\
\left(80^{\circ} \mathrm{C} / 40 \mathrm{MPa}\right)\end{array}$ & $\begin{array}{c}\text { Zaczyn C } \\
\left(80^{\circ} \mathrm{C} / 40 \mathrm{MPa}\right)\end{array}$ & $\begin{array}{c}\text { Zaczyn D } \\
\left(80^{\circ} \mathrm{C} / 40 \mathrm{MPa}\right)\end{array}$ \\
\hline Woda wodociągowa $(\mathrm{w} / \mathrm{c})^{* *}$ & 0,9 & 0,75 & 0,55 & 0,53 \\
\hline Bentonit & 1,5 & 1,0 & - & - \\
\hline Dodatek odpieniający (I) lub (II) & $0,3(\mathrm{I})$ & $0,3(\mathrm{I})$ & 0,4 (II) & 0,4 (II) \\
\hline Dodatek upłynniający (I) lub (II) & $0,2(\mathrm{I})$ & $0,2(\mathrm{I})$ & 0,2 (II) & 0,5 (II) \\
\hline $\begin{array}{l}\text { Dodatek antyfiltracyjny (I) polimer na } \\
\text { wysokie temperatury (II) }\end{array}$ & $0,6(\mathrm{I})$ & $0,6(\mathrm{I})$ & 0,6 (II) & 0,5 (II) \\
\hline Opóźniacz czasu gęstnienia (I) lub (II) & $0,5(\mathrm{I})$ & $0,5(\mathrm{I})$ & 0,4 (II) & 0,4 (II) \\
\hline $\mathrm{NaCl}^{* * *}$ & 20 & 20 & 20 & 20 \\
\hline Mikrocement (drobno mielony cement) & 10 & 10 & 5 & 10 \\
\hline Mikrosfery (obniżające gęstość zaczynu) & 10 & 5 & - & - \\
\hline Cement wiertniczy G HSR & 100 & 100 & 100 & 100 \\
\hline
\end{tabular}

* bwoc: tj. w stosunku do masy suchego cementu

${ }^{* *}$ w/c - stosunek wody (wyrażony w litrach) do masy suchego cementu (wyrażonej w kilogramach)

*** $\mathrm{NaCl}$ dodawany był $\mathrm{w}$ stosunku do masy wody zarobowej (bwow)

Tabela 8. Parametry technologiczne zaczynów cementowych dla kolumn rur technicznych (temperatura badania $80^{\circ} \mathrm{C}-$ rury $\left.9{ }^{5} / 8^{\prime \prime}\right)$

Table 8. Parameters of cement slurries for $95 / 8$ " intermediate casing tested at $80^{\circ} \mathrm{C}$

\begin{tabular}{|c|c|c|c|c|}
\hline $\begin{array}{c}\text { Symbol zaczynu, temperatura i ciśnienie/ } \\
\text { Oznaczany parametr }\end{array}$ & $\begin{array}{c}\text { Zaczyn A } \\
\left(80^{\circ} \mathrm{C} / 40 \mathrm{MPa}\right)\end{array}$ & $\begin{array}{c}\text { Zaczyn B } \\
\left(80^{\circ} \mathrm{C} / 40 \mathrm{MPa}\right)\end{array}$ & $\begin{array}{c}\text { Zaczyn C } \\
\left(80^{\circ} \mathrm{C} / 40 \mathrm{MPa}\right)\end{array}$ & $\begin{array}{c}\text { Zaczyn D } \\
\left(80^{\circ} \mathrm{C} / 40 \mathrm{MPa}\right)\end{array}$ \\
\hline Gęstość zaczynu $\left[\mathrm{kg} / \mathrm{m}^{3}\right]$ & 1530 & 1620 & 1820 & 1850 \\
\hline Odstój wody z zaczynu mierzony pod kątem $90^{\circ}[\%]$ & 0,0 & 0,0 & 0,0 & 0,0 \\
\hline Lepkość plastyczna zaczynu $[\mathrm{mPa} \cdot \mathrm{s}]$ & 33,0 & 40,5 & 76,5 & 88,5 \\
\hline Granica płynięcia zaczynu $[\mathrm{Pa}]$ & 7,7 & 6,5 & 18,5 & 20,4 \\
\hline $\begin{array}{l}\text { Czas uzyskania przez zaczyn konsystencji } 30 \mathrm{Bc} \\
\text { w warunkach HPHT [godziny:minuty] }\end{array}$ & $5: 23$ & $5: 34$ & $5: 15$ & $5: 10$ \\
\hline $\begin{array}{l}\text { Czas uzyskania przez zaczyn konsystencji } 100 \mathrm{Bc} \\
\text { w warunkach HPHT [godziny:minuty] }\end{array}$ & $5: 50$ & $6: 08$ & $5: 42$ & $5: 38$ \\
\hline Filtracja zaczynu cementowego $\left[\mathrm{cm}^{3} / 30\right.$ minut $]$ & 192 & 188 & 160 & 174 \\
\hline
\end{tabular}

Tabela 9. Składy obciążonych zaczynów cementowo-lateksowych dla kolumn rur eksploatacyjnych (temperatury badania $90^{\circ} \mathrm{C}$ i $120^{\circ} \mathrm{C}$ - rury $\left.7^{\prime \prime}\right)$

Table 9. Compositions of heavyweight latex cement slurries for 7" production casing tested at $90^{\circ}$ and $120^{\circ} \mathrm{C}$

\begin{tabular}{|c|c|c|c|c|}
\hline $\begin{array}{l}\text { Symbol zaczynu temperatura i ciśnienie/ } \\
\text { Składniki w [\%] bwoc }\end{array}$ & $\begin{array}{c}\text { Zaczyn E } \\
\left(90^{\circ} \mathrm{C} / 60 \mathrm{MPa}\right)\end{array}$ & $\begin{array}{c}\text { Zaczyn F } \\
\left(90^{\circ} \mathrm{C} / 60 \mathrm{MPa}\right)\end{array}$ & $\begin{array}{c}\text { Zaczyn G } \\
\left(120^{\circ} \mathrm{C} / 70 \mathrm{MPa}\right)\end{array}$ & $\begin{array}{c}\text { Zaczyn H } \\
\left(120^{\circ} \mathrm{C} / 70 \mathrm{MPa}\right)\end{array}$ \\
\hline Woda wodociągowa $(\mathrm{w} / \mathrm{c})$ & 0,34 & 0,40 & $\mathrm{w} / \mathrm{c}=0,38$ & $\mathrm{w} / \mathrm{c}=0,42$ \\
\hline Dodatek odpieniający (I) lub (II) & $0,5(\mathrm{I})$ & $0,5(\mathrm{I})$ & 0,3 (II) & 0,3 (II) \\
\hline Dodatek upłynniający (I) lub (II) & $0,5(\mathrm{I})$ & $0,5(\mathrm{I})$ & 0,4 (II) & 0,4 (II) \\
\hline Dodatek antyfiltracyjny (I) lub (II) & $0,15(\mathrm{I})$ & $0,3(\mathrm{I})$ & 0,2 (II) & 0,2 (II) \\
\hline Opóźniacz czasu gęstnienia (I) lub (II) & $0,2(\mathrm{I})$ & $0,2(\mathrm{I})$ & 0,4 (II) & 0,45 (II) \\
\hline $\mathrm{NaCl}$ (bwow) & 10 & 10 & 10 & 10 \\
\hline Lateks zagraniczny (odporny na wysokie temperatury) & 20 & 20 & 20 & 20 \\
\hline $\begin{array}{l}\text { Materiał obciążający (podnoszący gęstość zaczynu } \\
\text { cementowego) }\end{array}$ & 30 & 60 & 70 & 110 \\
\hline Mączka krzemionkowa & 10 & 35 & 10 & 10 \\
\hline Cement wiertniczy G HSR & 100 & 100 & 100 & 100 \\
\hline
\end{tabular}


Tabela 10. Parametry technologiczne obciążonych zaczynów cementowo-lateksowych dla kolumn rur eksploatacyjnych (temperatury badania $90^{\circ} \mathrm{C}$ i $120^{\circ} \mathrm{C}$ - rury $\left.7^{\prime \prime}\right)$

Table 10. Parameters of heavyweight latex cement slurries for 7" production casing tested at $90^{\circ}$ and $120^{\circ} \mathrm{C}$

\begin{tabular}{|c|c|c|c|c|}
\hline $\begin{array}{c}\text { Symbol zaczynu, temperatura i ciśnienie/ } \\
\text { Oznaczany parametr }\end{array}$ & $\begin{array}{c}\text { Zaczyn E } \\
\left(90^{\circ} \mathrm{C} / 60 \mathrm{MPa}\right)\end{array}$ & $\begin{array}{c}\text { Zaczyn F } \\
\left(90^{\circ} \mathrm{C} / 60 \mathrm{MPa}\right)\end{array}$ & $\begin{array}{c}\text { Zaczyn G } \\
\left(120^{\circ} \mathrm{C} / 70 \mathrm{MPa}\right)\end{array}$ & $\begin{array}{c}\text { Zaczyn H } \\
\left(120^{\circ} \mathrm{C} / 70 \mathrm{MPa}\right)\end{array}$ \\
\hline Gęstość zaczynu $\left[\mathrm{kg} / \mathrm{m}^{3}\right]$ & 2060 & 2180 & 2200 & 2350 \\
\hline Odstój wody z zaczynu mierzony pod kątem $90^{\circ}[\%]$ & 0,0 & 0,0 & 0,0 & 0,0 \\
\hline Lepkość plastyczna zaczynu $[\mathrm{mPa} \cdot \mathrm{s}]$ & 115,5 & 189,0 & 198,0 & 223,5 \\
\hline Granica płynięcia zaczynu [Pa] & 15,1 & 17,8 & 12,8 & 23,7 \\
\hline $\begin{array}{l}\text { Czas uzyskania przez zaczyn konsystencji } 30 \mathrm{Bc} \\
\text { w warunkach HPHT [godziny:minuty] }\end{array}$ & $3: 30$ & 3:01 & $3: 52$ & $4: 18$ \\
\hline $\begin{array}{l}\text { Czas uzyskania przez zaczyn konsystencji } 100 \mathrm{Bc} \\
\text { w warunkach HPHT [godziny:minuty] }\end{array}$ & $3: 43$ & $3: 13$ & $4: 20$ & $4: 40$ \\
\hline Filtracja zaczynu cementowego $\left[\mathrm{cm}^{3} / 30\right.$ minut] & 46 & 40 & 44 & 42 \\
\hline
\end{tabular}

Tabela 11. Składy zaczynów cementowo-lateksowych dla kolumn rur eksploatacyjnych (temperatury badania $130^{\circ} \mathrm{C}$ i $160^{\circ} \mathrm{C}-$ rury $5 "$ )

Table 11. Compositions of latex cement slurries for 5" production casing tested at $130^{\circ}$ and $160^{\circ} \mathrm{C}$

\begin{tabular}{|c|c|c|c|c|}
\hline $\begin{array}{c}\text { Symbol zaczynu temperatura i ciśnienie/ } \\
\text { Skladniki w [\%] bwoc }\end{array}$ & $\begin{array}{c}\text { Zaczyn J } \\
\left(130^{\circ} \mathrm{C} / 70 \mathrm{MPa}\right)\end{array}$ & $\begin{array}{c}\text { Zaczyn K } \\
\left(130^{\circ} \mathrm{C} / 70 \mathrm{MPa}\right)\end{array}$ & $\begin{array}{c}\text { Zaczyn L } \\
\left(160^{\circ} \mathrm{C} / 70 \mathrm{MPa}\right)\end{array}$ & $\begin{array}{c}\text { Zaczyn M } \\
\left(160^{\circ} \mathrm{C} / 70 \mathrm{MPa}\right)\end{array}$ \\
\hline Woda wodociągowa (w/c) & 0,54 & 0,54 & 0,50 & 0,50 \\
\hline Dodatek odpieniający (I) lub (II) & $0,3(\mathrm{I})$ & $0,3(\mathrm{I})$ & 0,5 (II) & 0,5 (II) \\
\hline Dodatek upłynniający (I) lub (II) & $0,3(\mathrm{I})$ & $0,3(\mathrm{I})$ & 1,5 (II) & 1,5 (II) \\
\hline $\begin{array}{l}\text { Dodatek antyfiltracyjny (I) lub polimer na wysokie } \\
\text { temperatury (II) }\end{array}$ & $0,2(\mathrm{I})$ & $0,2(\mathrm{I})$ & 1,2 (II) & 1,2 (II) \\
\hline Opóźniacz czasu gęstnienia (I) lub (II) & $0,45(\mathrm{I})$ & $0,55(\mathrm{I})$ & 1,0 (II) & 1,2 (II) \\
\hline $\mathrm{NaCl}$ (bwow) & 10 & 10 & 10 & 10 \\
\hline Mączka krzemionkowa & 15 & 15 & 10 & 10 \\
\hline Cement wiertniczy G HSR & 100 & 100 & 100 & 100 \\
\hline
\end{tabular}

Tabela 12. Parametry technologiczne zaczynów cementowo-lateksowych dla kolumn rur eksploatacyjnych (temperatury badania $130^{\circ} \mathrm{C}$ i $160^{\circ} \mathrm{C}$ - rury $\left.5^{\prime \prime}\right)$

Table 12. Parameters of latex cement slurries for 5 " production casing tested at $130^{\circ}$ and $160^{\circ} \mathrm{C}$

\begin{tabular}{|c|c|c|c|c|}
\hline $\begin{array}{l}\text { Symbol zaczynu, temperatura i ciśnienie/ } \\
\text { Oznaczany parametr }\end{array}$ & $\begin{array}{c}\text { Zaczyn J } \\
\left(130^{\circ} \mathrm{C} / 70 \mathrm{MPa}\right)\end{array}$ & $\begin{array}{c}\text { Zaczyn K } \\
\left(130^{\circ} \mathrm{C} / 70 \mathrm{MPa}\right)\end{array}$ & $\begin{array}{c}\text { Zaczyn L } \\
\left(160^{\circ} \mathrm{C} / 70 \mathrm{MPa}\right)\end{array}$ & $\begin{array}{c}\text { Zaczyn M } \\
\left(160^{\circ} \mathrm{C} / 70 \mathrm{MPa}\right)\end{array}$ \\
\hline Gęstość zaczynu $\left[\mathrm{kg} / \mathrm{m}^{3}\right]$ & 1870 & 1870 & 1910 & 1910 \\
\hline Odstój wody z zaczynu mierzony pod kątem $90^{\circ}[\%]$ & 0,0 & 0,0 & 0,0 & 0,0 \\
\hline Lepkość plastyczna zaczynu $[\mathrm{mPa} \cdot \mathrm{s}]$ & 91,5 & 93,0 & 123,0 & 129 \\
\hline Granica płynięcia zaczynu $[\mathrm{Pa}]$ & 13,7 & 19,2 & 5,8 & 7,2 \\
\hline $\begin{array}{l}\text { Czas uzyskania przez zaczyn konsystencji } 30 \mathrm{Bc} \\
\text { w warunkach HPHT [godziny:minuty] }\end{array}$ & $4: 10$ & $5: 14$ & $5: 58$ & 7:07 \\
\hline $\begin{array}{l}\text { Czas uzyskania przez zaczyn konsystencji } 100 \mathrm{Bc} \\
\text { w warunkach HPHT [godziny:minuty] }\end{array}$ & $4: 25$ & $5: 27$ & $6: 11$ & $7: 19$ \\
\hline Filtracja zaczynu cementowego $\left[\mathrm{cm}^{3} / 30\right.$ minut $]$ & 72 & 74 & nie badano & nie badano \\
\hline
\end{tabular}

znacznie niższe niż w dolomicie głównym cechsztynu i z tego powodu wymagane jest stosowanie zaczynów o gęstości około $1850-1900 \mathrm{~kg} / \mathrm{m}^{3}$, tj. bez udziału środków obciążających. $\mathrm{Z}$ uwagi na głębokie zaleganie warstw temperatura na dnie otworu może sięgać $120-130^{\circ} \mathrm{C}$, a nawet więcej. Opracowane w INiG - PIB receptury pozwalają na sprawne przeprowadzenie zabiegu uszczelniania linera 5". W tabeli 11 i 12 zaproponowano cztery receptury oznaczone symbolami: J, K, $\mathrm{L}$ oraz $\mathrm{M}$ (dwie pierwsze receptury badano $\mathrm{w} 130^{\circ} \mathrm{C}$, a dwie kolejne $\mathrm{w} 160^{\circ} \mathrm{C}$ ). Zaczyny sporządzano na $10 \%$ solance 
$\mathrm{NaCl}$ na bazie cementu G HSR. W skład zaczynów wchodziły dodatki odpieniające, upłynniające, antyfiltracyjne oraz opóźniacze wiązania, a także mączka krzemionkowa podnosząca wytrzymałość mechaniczną. Zaczyny cechowały się gęstością od około 1870 do około $1910 \mathrm{~kg} / \mathrm{m}^{3}$ i zerowym odstojem wody. Ich lepkości wynosiły od około $90 \mathrm{mPa} \cdot \mathrm{s}$

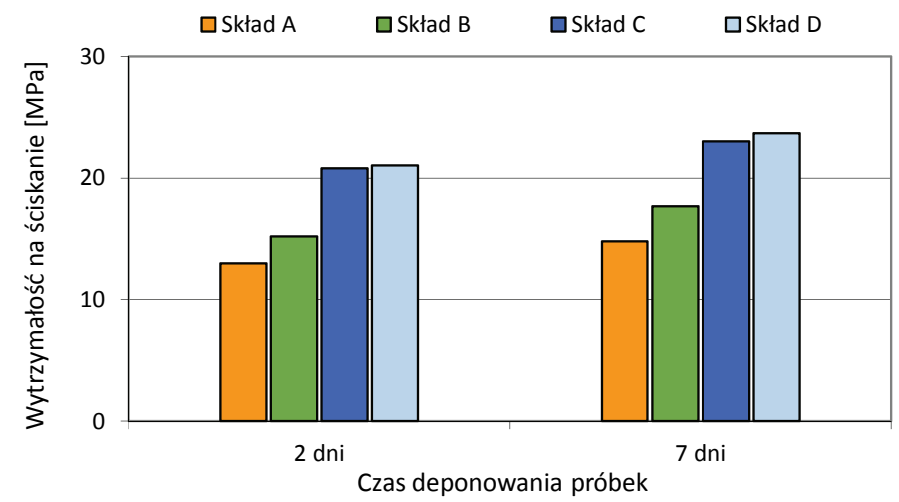

Rys. 4. Wytrzymałości na ściskanie po 2 i 7 dniach dla próbek A, $\mathrm{B}, \mathrm{C}$ oraz D badanych w temperaturze $80^{\circ} \mathrm{C}$

Fig. 4. Compressive strength after 2 and 7 days for samples A, B, $\mathrm{C}$ and $\mathrm{D}$ tested at $80^{\circ} \mathrm{C}$

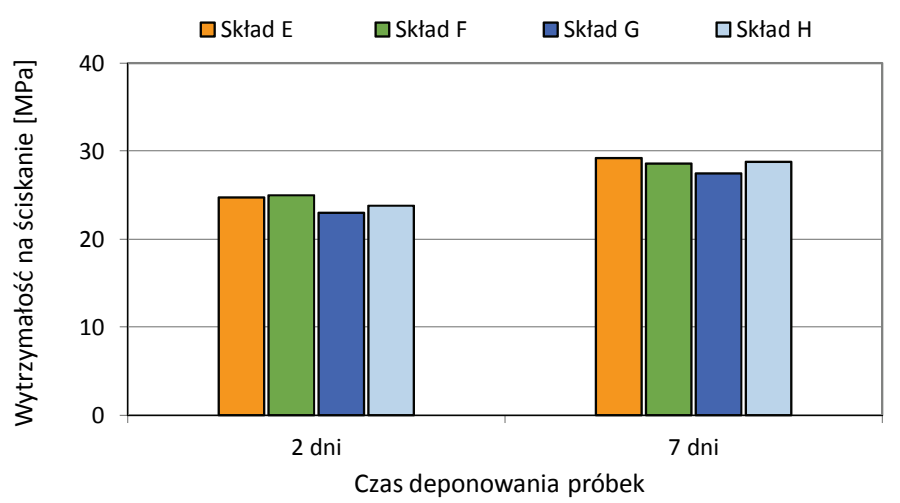

Rys. 5. Wytrzymałości na ściskanie po 2 i 7 dniach dla próbek E, $\mathrm{F}, \mathrm{G}$ oraz $\mathrm{H}$ badanych w temperaturze $90^{\circ} \mathrm{C}$ i $120^{\circ} \mathrm{C}$

Fig. 5. Compressive strength after 2 and 7 days for samples E, F, $\mathrm{G}$ and $\mathrm{H}$ tested at $90^{\circ} \mathrm{C}$ and $120^{\circ} \mathrm{C}$

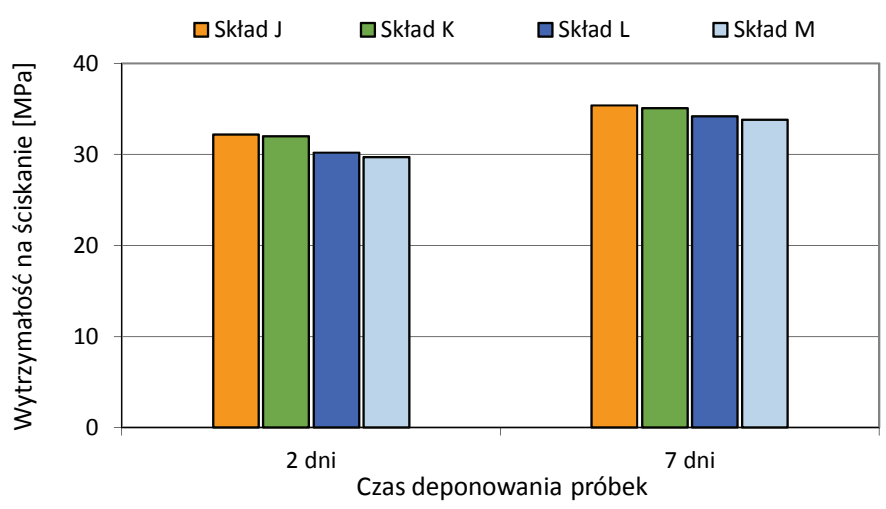

Rys. 6. Wytrzymałości na ściskanie po 2 i 7 dniach dla próbek J, $\mathrm{K}$, L oraz M badanych w temperaturze $130^{\circ} \mathrm{C}$ i $160 \mathrm{C}$

Fig. 6. Compressive strength after 2 and 7 days for samples J, K, L and $\mathrm{M}$ tested at $130^{\circ} \mathrm{C}$ and $160^{\circ} \mathrm{C}$ do około $130 \mathrm{mPa} \cdot \mathrm{s}$. Czasy początku gęstnienia $(30 \mathrm{Bc})$ zaczynów $\mathrm{J}$ i K (badanych w $130^{\circ} \mathrm{C}$ ) były równe około $4 \frac{1}{2}-5^{1 / 2}$ godziny, a zaczynów Li M około 6-7 godzin. Parametry mechaniczne kamieni cementowych powstałych z badanych receptur zamieszczono na rysunku 6 . Wartości wytrzymałości na ściskanie po 2 dniach osiągały wartości około $30 \mathrm{MPa}$, a po 7 dniach około 33-35 MPa.

\section{Podsumowanie}

Na podstawie badań laboratoryjnych w INiG - PIB opracowane zostały receptury zaczynów cementowych do uszczelniania kolumn rur okładzinowych o średnicach 95/8", 7" oraz 5" na obszarze Niżu Polskiego. Sporządzane zaczyny zarabiane były $10 \%$ lub $20 \%$ solanką $\mathrm{NaCl}$. Wykonywano je na bazie cementu wiertniczego G HSR o podwyższonej odporności na siarczany.

1. Receptury dla poszczególnych kolumn rur technicznych i eksploatacyjnych dobierano w zależności od warunków otworowych panujących podczas prowadzenia prac wiertniczych.

2. Do uszczelniania kolumn rur 95/8" zaproponowano dwa rodzaje zaczynów: „lekkie” oraz o „normalnej” gęstości, które badano w temperaturze $80^{\circ} \mathrm{C}$. Dla kolumny rur 7" zamieszczono propozycję ciężkich zaczynów cementowych (o regulowanej gęstości) testowanych $\mathrm{w} 95^{\circ} \mathrm{C}$ i $120^{\circ} \mathrm{C}$. Z kolei dla kolumn rur 5" opracowano receptury o „,normalnej” gęstości dla temperatur $130^{\circ} \mathrm{C} \mathrm{i} 160^{\circ} \mathrm{C}$.

3. Parametry technologiczne opracowanych receptur cementowych mogą być z powodzeniem regulowalne za pomocą dodatków i domieszek dostępnych na krajowym rynku.

4. Wprowadzenie do zaczynu dodatków obniżających gęstość (w przypadku zaczynu górnego dla rur 95/8”) pozwoliło na uzyskanie receptur o regulowanej gęstości od około $1500-1650 \mathrm{~kg} / \mathrm{m}^{3}$.

5. Dodatek obciążający dodawany do receptur proponowanych do uszczelniania rur 7" pozwolił na opracowanie zaczynów o gęstości w granicach od około 2060 do około $2350 \mathrm{~kg} / \mathrm{m}^{3}$.

6. Zastosowanie odpowiednio dobranych opóźniaczy wiązania nowej generacji umożliwiło sporządzanie receptur dla bardzo wysokich temperatur $\left(\right.$ do $\left.160^{\circ} \mathrm{C}\right)$.

7. Wykonane w INiG - PIB zaczyny cementowe po dobraniu odpowiednich środków upłynniających charakteryzują się dobrymi parametrami reologicznymi. Ich lepkości plastyczne wynosiły około $35-40 \mathrm{mPa} \cdot \mathrm{s}$ (w przypadku zaczynów „lekkich”) około 90-120 mPa · s (dla zaczynów o „normalnej” gęstości) około 180-220 mPa · s (w przypadku zaczynów obciążonych). 
8. Czasy początku gęstnienia opracowanych zaczynów cementowych (tj. uzyskanie konsystencji 30 Bc) wynoszą w zależności od potrzeb od około $3 \frac{1}{2}$ do około 7 godzin i można je z powodzeniem regulować dodatkiem odpowiedniego środka opóźniającego. Lepkości początkowe zaczynów badanych w konsystometrze ciśnieniowym są niewielkie (około 10-15 Bc), a przebieg zmian konsystencji zaczynów cementowych ma charakter, ,prostokątny" (tzn. czas pomiędzy uzyskaniem konsystencji $30 \mathrm{Bc}$ a 100 Bc jest krótki).

9. Filtracje zaczynów z dodatkiem lateksu nie przekraczały $50 \mathrm{~cm}^{3} / 30$ minut. Zaczyny nie zawierające lateksu posiadały filtrację poniżej $200 \mathrm{~cm}^{3} / 30$ minut. Wszystkie opracowane w INiG - PIB zaczyny cechowały się zerowym odstojem wody.

10. Kamienie cementowe powstałe po związaniu zaczynów posiadały odpowiednio wysokie parametry mechaniczne. Po okresie 2 dni hydratacji wytrzymałość na ściskanie lekkich kamieni cementowych badanych w temperaturze $80^{\circ} \mathrm{C}$ przekraczała $13 \mathrm{MPa}$. Kamienie cementowe powstałe z zaczynów ciężkich testowane w temperaturze od 95 do $120^{\circ} \mathrm{C}$ posiadały wytrzymałość na ściskanie około 22-25 MPa, a próbki o ,normalnej” w temperaturze $130-160^{\circ} \mathrm{C}$ około $30 \mathrm{MPa}$. Wytrzymałości mechaniczne próbek po okresie 7 dni hydratacji wzrastały z reguły o około $15 \%$ w porównaniu z wartościami uzyskiwanymi po 2 dniach.

11. Opracowane receptury zaczynów mogą znaleźć zastosowanie w procesie cementowania kolumn rur okładzinowych podczas prac prowadzonych na Niżu Polskim w trudnych warunkach geologiczno-technicznych.

Artykuł powstał na podstawie pracy statutowej pt.: Zaczyny cementowe o regulowanych parametrach reologicznych dla wysokich temperatur złożowych - praca INiG - PIB na zlecenie MNiSW; nr zlecenia: 0061/KW/2017, nr archiwalny: DK-4100-0048/2017.

\section{Literatura}

Anjos M.A.S., Martinelli A.E., Melo D.M.A., Renovato T., Souza P.D.P., Freitas J.C., 2013. Hydration of oil well cement containing sugarcane biomass waste as a function of curing temperature and pressure. Journal of Petroleum Science and Engineering, 109: 291-297. DOI: 10.1016/j.petrol.2013.08.016.

Bensted J., 1991. Retardation of Cement Slurries to $250^{\circ}$ F. Society of Petroleum Engineers. DOI: 10.2118/23073-MS.

Boul P.J., Ellis M., Thaemlitz C.J., 2016. Retarder Interactions in Oil Well Cements. American Association of Drilling Engineers AADE, Houston, TX: 1-7.

Brylicki W., 2001. Czynniki determinujące trwałość betonu i iniekcyjnych zaczynów cementowych. Sympozjum Naukowo-Techniczne „Cementy w budownictwie, robotach wiertniczych i inżynieryjnych oraz hydrotechnice", Piła-Płotki: 57-79.
Dębińska E., 2012. Ocena działania dodatków opóźniających czas wiązania zaczynów cementowych na podstawie badań laboratoryjnych. Nafta-Gaz, 4: 225-232.

Gonet A., Stryczek S., Pinka J., 2004. Analysis of Rheological Models of Selected Cement Slurries. Acta Montanistica Slovaca, 9(1): $16-20$.

Herman Z., Migdał M., 1998. Problemy cementowania rur okładzinowych na Niżu Polskim. Nafta-Gaz, 12: 542-553.

Nalepa J., 2001. Problemy związane z cementowaniem głębokich otworów wiertniczych. Sympozjum Naukowo-Techniczne „Cementy w budownictwie, robotach wiertniczych i inżynieryjnych oraz hydrotechnice", Piła-Płotki: 95-103.

Nelson E.B., 1990. Well Cementing. Schlumberger Educational Service, Houston, TX, USA.

Rzepka M., Kremieniewski M., 2017. Zaczyny cementowe do uszczelniania głębokich otworów wiertniczych. Oil and Gas Engineering, Poltava National Technical University, 2: 43-56.

Rzepka M., Kremieniewski M., Dębińska E., 2012. Zaczyny cementowe przeznaczone do uszczelniania eksploatacyjnych kolumn rur okładzinowych na Niżu Polskim. Nafta-Gaz, 8: 512-522.

Rzepka M., Stryczek S., 2008. Laboratoryjne metody określania parametrów technologicznych świeżych zaczynów uszczelniających przed zabiegiem związanym z procesem uszczelniania kolumn rur okładzinowych w otworach wiertniczych. Wiertnictwo, Nafta, Gaz, 25(2): 625-636.

Salim P., Amani M., 2013. Special considerations in cementing high pressure high temperature wells. International Journal of Engineering and Applied Sciences, 1(4): 120-146.

Souza P.P., Soares R.A., Anjos M.A., Freitas J.O., Martinelli A.E., Melo D.F., 2012. Cement slurries of oil wells under high temperature and pressure: the effects of the use of ceramic waste and silica flour. Brazilian Journal of Petroleum and Gas, 6(3): 104-113. DOI: 10.5419/bjpg2012-0009.

Stryczek S., Gonet A., 2001. Wymagania odnośnie zaczynów uszczelniających stosowanych w technologiach wiertniczych. Sympozjum Naukowo-Techniczne ,, Cementy w budownictwie, robotach wiertniczych i inżynieryjnych oraz hydrotechnice", Piła-Płotki: 31-41.

\section{Akty prawne i normatywne}

PN-EN ISO 10426-1:2009 Przemyst naftowy i gazowniczy - Cementy i materiały do cementowania otworów - Część 1: Specyfikacja.

PN-EN ISO 10426-2:2003 Przemyst naftowy i gazowniczy - Cementy i materiaty do cementowania otworów wiertniczych - Część 2 : Badania cementów wiertniczych.

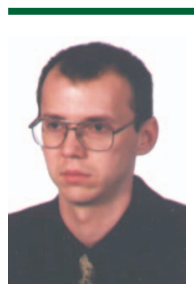

Dr inż. Marcin RZEPKA

Kierownik Laboratorium Zaczynów Uszczelniających w Zakładzie Technologii Wiercenia Instytut Nafty i Gazu - Państwowy Instytut Badawczy ul. Lubicz $25 \mathrm{~A}$

31-503 Kraków

E-mail: marcin.rzepka@inig.pl

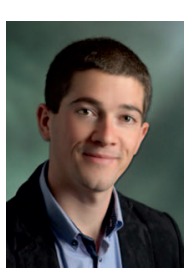

Mgr inż. Miłosz KĘDZIERSKI

Specjalista inżynieryjno-techniczny w Zakładzie Technologii Wiercenia

Instytut Nafty i Gazu - Państwowy Instytut Badawczy ul. Lubicz 25 A

31-503 Kraków

E-mail: milosz.kedzierski@inig.pl 